\title{
Migraine treatment with external trigeminal nerve stimulation: current knowledge on mechanisms
}

\author{
Jean Schoenen MD, PhD
}

\author{
Author detail: \\ Jean Schoenen MD, $\mathrm{PhD}$ \\ Headache Research Unit. \\ Department of Neurology- \\ Citadelle Hospital. \\ University of Liège. \\ Belgium. \\ Email: \\ jschoenen@ulg.ac.be
}

\section{Corresponding author:}

Prof. Dr. Jean Schoenen

University Department of

Neurology.

Citadelle Hospital.

Blvd du XII de Ligne, 1 4000 LIEGE. Belgium

Tel +32 43218663

Email:

jschoenen@ulg.ac.be

\section{Abstract}

Available pharmacological migraine treatments have incomplete efficacy and many of them may have intolerable adverse effects. There is thus a need for alternative, more efficient and better tolerable therapies. Pericranial nerve stimulation methods represent such an alternative. Methods using implantable electrodes and stimulators can be used in the most severely disabled patients due their invasive nature and high adverse event rate. Thanks to technological advances, non-invasive, user-friendly, transcutaneous stimulators have been developed recently and are applicable also in less disabled patients. In particular, supraorbital external trigeminal nerve stimulation (eTNS) with the Cefaly ${ }^{\circledR}$ device was found effective for migraine prevention in a randomized, sham-controlled trial, two open studies and one post-market survey. Non-controlled pilot studies and an Internet survey suggest that the device is also useful for migraine attack treatment; the results of a sham-controlled trial are about to be published.

The mode of action of eTNS in migraine is not fully understood. Like extra-cephalic transcutaneous electrical nerve stimulation (TENS), eTNS may have segmental "gate control" mechanisms as well as supra-segmental actions. Scarce evidence for a segmental mechanism comes from a pilot study of 10 patients in whom amplitude of the nociceptive blink reflex (nBR) was transiently reduced after one 20-min eTNS session. In healthy subjects, $1 \mathrm{~Hz}$ noxious stimulation of the supra-orbital nerve produces a long-lasting reduction of the $\mathrm{nBR}$ and homotopic pain perception, while 3 $\mathrm{Hz}$ stimulation of the greater occipital nerve has no effect on the nBR. A single session of eTNS in migraine patients during an attack relieves pain transiently, but it has no effect on cerebral metabolism. Conversely, after several months of eTNS with the Cefaly ${ }^{\circledR}$, there is an increase in metabolism assessed with FDP-PET in pre-treatment hypo-metabolic medial prefrontal cortical areas, including anterior cingulate cortex, while trigeminal noxious heat-induced fMRI BOLD hyper-activation of the latter normalises. These metabolic changes are accompanied by a significant decrease in monthly attack frequency in compliant patients.

Taken together, available data suggest that mode and site of Cefaly ${ }^{\circledR}, s$ action may differ between its acute and 
preventive anti-migraine effects. While it may relieve headache during an attack by a segmental, somatic afferent-induced blockade of nociceptive trigeminovascular afferents in trigeminal nucleus caudalis, its preventive effect more likely depends on a slow modulatory suprasegmental mechanism that normalises activity in cortical areas controlling pain and its behavioural aspects. The correlations between segmental or supra-segmental actions and therapeutic efficacy need to be further investigated.

Key words: Migraine, acute treatment, preventive treatment, external trigeminal nerve stimulation, mode of action 


\section{Introduction}

Migraine management includes acute and preventive treatments. While acute treatments aim at interrupting an attack and restore normal function (1), preventive treatments have the disease-modifying objective of reducing attack frequency and severity (2). Currently, migraine is mostly managed with pharmacologic treatments. The most commonly used drugs to interrupt migraine attacks are analgesics, non-steroidal anti-inflammatory drugs (NSAIDs), and triptans (3). Effective preventive drugs include beta-blockers without intrinsic sympathicomimetic activity, calcium channel blockers, sartans and the anti-convulsants topiramate and valproate (4), as well as nutraceuticals like riboflavin and co-enzyme Q10 (5).

Besides the latter, most preventive antimigraine drugs are associated with moderate to severe side effects, have contraindications and only partial efficacy leading frequently to dissatisfaction and discontinuation by the patients $(6,7,8)$. Consequently, $80 \%$ of patients are willing to change their current medication for a treatment with similar efficacy but fewer side effects (9). Last but not least, in patients with frequent and/or prolonged migraine attacks, excessive consumption of acute anti-migraine drugs may lead to headache chronification, i.e., medication overuse headache, which worsens the patients' condition (10)

\section{The Clinical Evidence}

The shortcomings of pharmacological migr-aine management underscore the need for better treatments and have created a niche for non-pharmacologic therapies such as neurostimulation. Peripheral nerve stimulation (PNS) is not a novel approach to treat headaches (see 11 for review). Percutaneous nerve stimulation was reported effective for the treatment of various headaches since the 90s $(12,13)$. Occipital nerve stimulation
(ONS) was beneficial for chronic migraine in sham-controlled trials, although the global effect size was modest $(14,15,16)$. The combination of percutaneous ONS and supraorbital nerve stimulation (SNS) was claimed to have a better effect, but randomized controlled trials are lacking (17). The common drawback of these neurostimulation methods is that they are invasive and applicable only to the most disabled patients with frequent, severe and drug-refractory migraine (18).

The development of non-invasive trans-cutaneous stimulators opened the neuro-stimulation field to all migraine patients without consideration of disability or drug-refractoriness (see 19 for a review). The first studies showing beneficial effects in various headache types were published as early as 1985 (20, 21, 22, 23), the singleblinded placebo-controlled trial by Solomon and Guglielmo (20) being the most convincing.

It took 2 decades before technological advances allowed developing a portable, user-friendly and more effective external trigeminal stimulator (eTNS), the Cefaly $^{\circledR}$ (Cefaly Technology sprl, GrâceHollogne, Belgium). The Cefaly ${ }^{\circledR}$ device stimulates transcutaneously supraorbital branches of the ophthalmic nerve and in the randomised, sham-controlled, blinded PREMICE trial (24), effective stimulation (pulse width $250 \mu \mathrm{s}, 60 \mathrm{~Hz}$ stimulation frequency, $16 \mathrm{~mA}$ intensity, 20-min daily application) was found clearly superior to sham stimulation (pulse width $30 \mu \mathrm{s}, 1 \mathrm{~Hz}$ frequency, $1 \mathrm{~mA}$ intensity) for the prevention of episodic migraine. After 3 months of treatment, mean number of monthly migraine days was significantly decreased and $38.1 \%$ of the 34 effectively treated patients had $\mathrm{a} \geq 50 \%$ reduction in migraine days compared to $12.1 \%$ in the 33 shamtreated patients. There were no adverse events. For comparison, in the pooled 
analysis of topiramate RCTs, the $50 \%$ responder rate was $45.3 \%$, but $50 \%$ of patients had drug-related side effects and 1 out of 4 patients abandoned treatment because of intolerable adverse effects (25). As a consequence of the PREMICE trial, in March 2014 Cefaly ${ }^{\circledR}$ was the first medical device approved by the FDA for the prevention of migraine. Its beneficial preventive effect in low-frequency migraine was also suggested by a small open study in 24 drug-naive migraineurs (26) and a prospective registry involving 2,313 patients showed that eTNS is a well tolerated and safe therapy with mild adverse events reported by only $4.3 \%$ of patients (27).

Although in clinical practice many patients report using Cefaly® during migraine attacks with a beneficial effect on headache and disability, only limited evidence is available for its efficiency in acute migraine treatment published in abstracts. In a pilot trial of 10 episodic migraine patients who treated 3 successive attacks with the device, total relief without rescue medication was obtained in $12 \%$ of attacks at 30 minutes, incomplete relief with rescue medication in $42.5 \%$ and no effect in $45.5 \%$ (28). In an open study of 16 patients, the Cefaly ${ }^{\circledR}$ device was effective and welltolerated as rescue therapy for migraine attack symptoms present since at least 72 hours; it reduced the migraine headache on average by $46 \%$, and $56 \%$ of patients declared they would like to use the device again (29). In another open study, Chou et al. (30) treated 30 patients during an attack in the hospital for 1 hour, which resulted on average in a 57\% decrease of headache intensity. The sham-controlled trial with a similar protocol is about to be completed (see table 1). We recently published the results of an Internet survey on migraine attack treatment with the Cefaly ${ }^{\circledR}$ in 463 regular users using a structured questionnaire: $88.6 \%$ of them reported using the device in $71.8 \%$ of their attacks; the use of the device allowed a reduction of acute medication intake in $42.6 \%$ of attacks (31).

The precise mode of action of pericranial nerve neurostimulation methods in migraine remains to be determined. Recent neuroimaging studies, however, may shed light on possible relevant mechanisms.

\begin{tabular}{|c|c|c|c|}
\hline \multicolumn{4}{|c|}{ MIGRAINE PREVENTION } \\
\hline Study protocol & $\begin{array}{l}\text { Number } \\
\text { of patients }\end{array}$ & Outcome & References \\
\hline $\begin{array}{l}\text { Open-pilot } \\
3 \text { months }\end{array}$ & $\begin{array}{l}10 \text { episodic } \mathrm{MO} \\
\text { patients }\end{array}$ & $\begin{array}{l}-1.3 \text { reduction in monthly } \\
\text { attack frequency } \\
5 / 10 \text { patients satisfied }\end{array}$ & $\begin{array}{l}\text { Gérardy et al. } \\
\text { Cephalalgia } 2009 \\
\text { (abstract) (28) }\end{array}$ \\
\hline $\begin{array}{l}\text { Multicenter, double- } \\
\text { blind, randomized, } \\
\text { sham-controlled } \\
3 \text { months }\end{array}$ & $\begin{array}{l}67 \text { episodic MO } \\
\text { patients ( } 34 \text { verum, } \\
33 \text { sham) }\end{array}$ & $\begin{array}{l}\geq 50 \% \text { responder rate } \\
\text { Verum: } 38.1 \% \\
\text { Sham: } 12.1 \%\end{array}$ & $\begin{array}{l}\text { Schoenen et al. } \\
\text { Neurology } 2013 \\
(24)\end{array}$ \\
\hline $\begin{array}{l}\text { Open } \\
2 \text { months }\end{array}$ & $\begin{array}{l}20 \text { drug-naïve } \\
\text { episodic MO } \\
\text { patients }\end{array}$ & $\begin{array}{l}\geq 50 \% \text { responder rate: } \\
81 \%\end{array}$ & $\begin{array}{l}\text { Russo et al. } \\
\text { J Head Pain } 2015 \\
(26)\end{array}$ \\
\hline $\begin{array}{l}\text { Survey } \\
\text { of prospective } \\
\text { company registry }\end{array}$ & $\begin{array}{l}2,313 \text { migraineurs } \\
\text { testing the Cefaly }{ }^{\circledR}\end{array}$ & $\begin{array}{l}54.4 \% \text { satisfied \& willing } \\
\text { to buy after a } 58 \text {-day test } \\
4.4 \% \text { report adverse } \\
\text { events }(2.03 \% \text { : local } \\
\text { intolerance) }\end{array}$ & $\begin{array}{l}\text { Magis et al. } \\
\text { J Head Pain } 2013 \\
(27)\end{array}$ \\
\hline
\end{tabular}




\begin{tabular}{|c|c|c|c|}
\hline $\begin{array}{l}\text { Open } \\
3 \text { months }\end{array}$ & $\begin{array}{l}\text { Prevention } \\
\text { in } 50 \text { chronic } \\
\text { migraine patients }\end{array}$ & On-going & $\begin{array}{l}\text { ClinicalTrials.gov } \\
\text { Identifier: } \\
\text { NCT02342743 }\end{array}$ \\
\hline \multicolumn{4}{|c|}{ ATTACK TREATMENT } \\
\hline $\begin{array}{l}\text { Open-pilot } \\
\text { Non-treated attacks }\end{array}$ & $\begin{array}{l}10 \text { episodic } \mathrm{MO} \\
\text { patients } \\
3 \text { attacks }\end{array}$ & $\begin{array}{l}\text { Attack outcome at } 30 \\
\text { min: } \\
12 \% \text { - total relief } \\
45 \% \text { - partial relief } \\
43 \% \text { - no effect }\end{array}$ & $\begin{array}{l}\text { Gérardy et al. } \\
\text { Cephalalgia } 2009 \\
\text { (abstract) (28) }\end{array}$ \\
\hline $\begin{array}{l}\text { Open } \\
\text { Rescue for attacks } \\
\text { of } \geq 72 \mathrm{~h}\end{array}$ & $\begin{array}{l}16 \text { episodic } \mathrm{MO} \\
\text { patients }\end{array}$ & $\begin{array}{l}46 \% \text { reduction of } \\
\text { headache } \\
56 \% \text { patients like to use } \\
\text { it again }\end{array}$ & $\begin{array}{l}\text { Kozminski. } \\
\text { Headache } 2014 \\
\text { (abstract) (29) }\end{array}$ \\
\hline $\begin{array}{l}\text { Open } \\
\text { In-hospital } 1 \mathrm{~h} \\
\text { treatment } \\
\text { Attack duration } \geq 3 \mathrm{~h}\end{array}$ & $\begin{array}{l}30 \text { episodic } \mathrm{MO} \\
\text { patients }\end{array}$ & $\begin{array}{l}\text { At } 1 \text { hour: } \\
57 \% \text { reduction in head } \\
\text { pain } \\
77 \% \text { of patients with } \\
50 \% \text { pain relief }\end{array}$ & $\begin{array}{l}\text { Chou et al. } \\
\text { Headache } 2016 \\
\text { (abstract) (30) }\end{array}$ \\
\hline $\begin{array}{l}\text { Internet survey } \\
\text { by questionnaire }\end{array}$ & $\begin{array}{l}413 \text { physician- } \\
\text { diagnosed } \\
\text { migraineurs } \\
\text { Regular Cefaly } \\
\text { users } \\
\end{array}$ & $\begin{array}{l}88.6 \% \text { use the device in } \\
71.8 \% \text { of attacks } \\
42.6 \% \text { device-treated } \\
\text { attacks with reduction of } \\
\text { acute migraine drugs }\end{array}$ & $\begin{array}{l}\text { Penning \& } \\
\text { Schoenen } \\
\text { Acta Neurol Belg } \\
2017 \text { (31) }\end{array}$ \\
\hline $\begin{array}{l}\text { Multicenter, double } \\
\text { blind, randomized, } \\
\text { sham-controlled, } \\
\text { in-hospital lhour }\end{array}$ & $\begin{array}{l}90 \text { episodic } M O \\
\text { patients }\end{array}$ & On-going & $\begin{array}{l}\text { ClinicalTrials.gov } \\
\text { Identifier: } \\
\text { NCT02590939 }\end{array}$ \\
\hline
\end{tabular}

Table 1: Synopsis of published and on-going clinical studies of external trigeminal nerve stimulation with the $\mathrm{Cefaly}^{\circledR}$ device in migraine. MO: migraine without aura. Italics: on-going trials. 


\section{Possible Mechanisms of Action}

The initial rationale for the use of pericranial nerve stimulation in migraine postulated that convergence of somatic afferents from the trigeminal or the C2 territories with visceral trigeminovascular afferents on spinal trigeminal nucleus $2^{\text {nd }}$ order nociceptors might block ascending impulses in the pain pathway. Like transcutaneous electrical nerve stimulation (TENS) known to relieve neuropathic pain since many years (32), it was thought that peripheral nerve stimulation could block nociceptive activity at the segmental level via activation of large $\mathrm{A} \beta$ afferents according to Melzack \& Wall's gate control theory $(33,34)$. While this might be true for conventional low intensity-high frequency TENS, acupuncture-like high intensity-low frequency TENS and high intensity-high frequency TENS, resembling the Cefaly ${ }^{\circledR}$ stimulation pattern, are more likely to engage extrasegmental mechanisms like activation of subcortical pain control centres (35). We will successively examine the evidence for a segmental and a suprasegmental mode of action of eTNS in migraine therapy.

\subsection{Peripheral mechanisms}

The stimuli generated by eTNS generate nerve impulses that can in theory collide with noxious orthodromic afferent signals and extinguish them. This is more likely when A $\delta$ fibers are activated by high intensity stimulation. Such a mechanism cannot play a significant role in migraine where somatic nociceptive afferents of the ophthalmic nerve are not supposed to be involved in headache generation, contrary to the visceral afferents of the trigeminovascular system. It was found recently, however, that branches of meningeal nociceptive fibers emerge at the level of cranial emissary canals and fissures to innervate extracranial structures like periosteum and muscles (36). These fibers have been described in the temporal, parietal and occipital areas and originate from the mandibulary and maxillary portions of the trigeminal ganglion, not from the ophthalmic division. Due to the anatomical position and the small surface of its supraorbital electrode, the Cefaly ${ }^{\circledR}$ device is unlikely to activate significant numbers of these extracranial meningeal afferents.

High intensity-low frequency TENS over muscles produces strong but comfortable muscle contraction that can activate muscle afferents to elicit analgesia (35). Interestingly, quantitative electromyography (EMG) recordings in 23 chronic migraine patients during eTNS with the Cefaly $^{\circledR}$ showed an increase of median frequency and amplitude of the myoelectrical signal in anterior temporalis, auricularis posterior, and middle trapezius muscles, but not in frontalis (37). The significance of this finding for the mode of action of the device is doubtful, the more so that it is unlikely that pericranial muscle activity plays a pathogenic role in chronic migraine (38).

\subsection{Segmental mechanisms}

The hypothesis that pericranial nerve stimulation would be able to decrease trigeminal nociception by a segmental mechanism comparable to the gate control theory was not confirmed in several experimental studies. In rats, stimulation of the greater occipital nerve increased central excitability of $2^{\text {nd }}$ order nociceptors activated by dural afferents in the trigeminocervical complex (39). In humans, low frequency $(3 \mathrm{~Hz})$ nociceptive stimulation of the greater occipital nerve had no effect on amplitude of the nociceptive blink reflex (nBR), a surrogate marker of spinal trigeminal nucleus excitability (40). By contrast, $1 \mathrm{~Hz}$ noxious stimulation of the supra-orbital skin induced a long-lasting 
depression of $\mathrm{nBR}$ amplitude and homotopic pain ratings in normal subjects, which was thought to be due to long term depression of $2^{\text {nd }}$ order nociceptors in the spinal trigeminal nucleus (41). In an accompanying editorial, Cruccu and Truini (42) suggest that low frequency-high intensity acupuncture-like electrical stimulation could be a great opportunity in pain therapy, because it might attenuate the long-term potentiation of dorsal horn nociceptive synapses that contribute to hyperalgesia and allodynia.
Unlike Aymanns et al.'s study (41), eTNS with Cefaly $^{\circledR}$ uses high frequency stimulation. Nonetheless, in the abovementioned pilot study (28), we tested the effect of one $20 \mathrm{~min}$ session of stimulation with the device $(60 \mathrm{~Hz}, 16 \mathrm{~mA})$ on amplitude and habituation of the $\mathrm{nBR}$ in 10 migraineurs. Immediately after the stimulation, there was a mild, but significant decrease of nBR amplitude and a more pronounced decrease of habituation (Fig. 1)
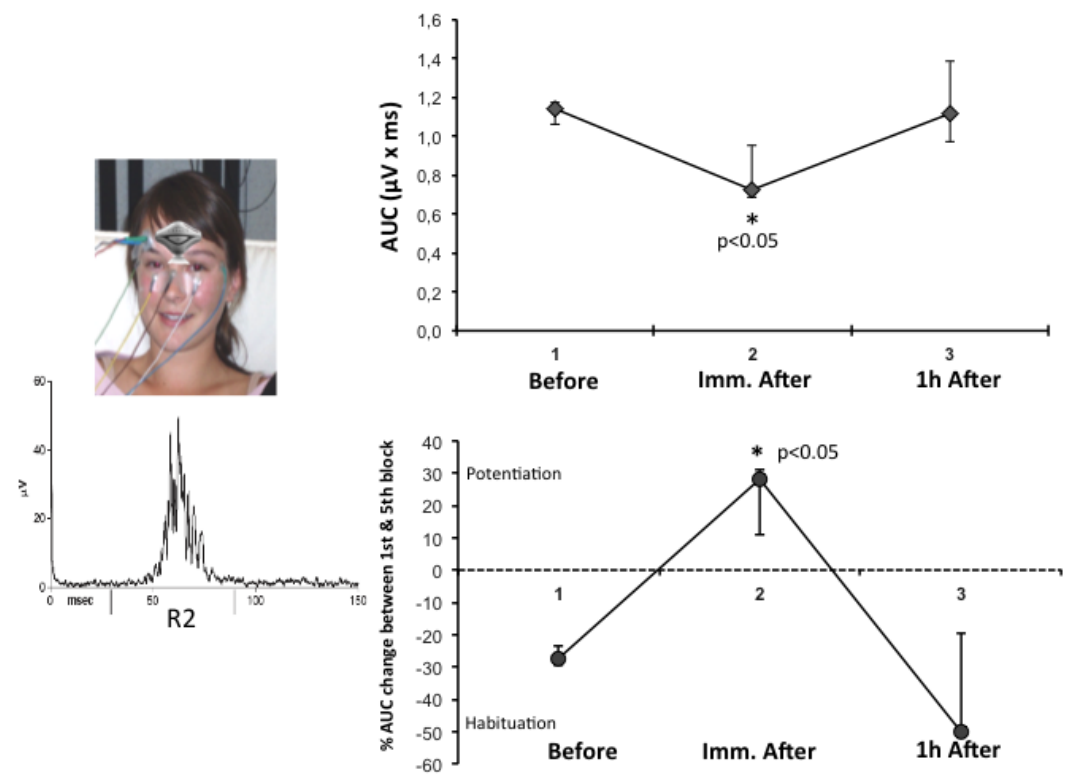

Figure 1: nBR changes after one 20 min session with the Cefaly ${ }^{\circledR}(60 \mathrm{~Hz}, 16 \mathrm{~mA})$ (set-up and an illustrative recording on the left). Upper right: histogram of changes in area under the curve (AUC-average of 5 rectified responses) immediately after and $1 \mathrm{~h}$ after the eTNS session. Lower right: histogram of change in AUC over 3 successive blocks of 5 averaged responses before and after eTNS.

In another group of 15 migraine without aura patients between attacks, we also recorded contact heat-evoked potentials (CHEPs), a thermonociceptive cortical evoked response, before and after a single session with the Cefaly ${ }^{\circledR}$. As shown in Figure 2, eTNS significantly decreased the amplitude of the CHEP obtained by a heat stimulus to the frontal skin, but not that of the CHEP elicited by stimulation at the wrist. The eTNS-induced decrease of the thermonociceptive potential is thus homotopic, suggesting that eTNS modulates nociception via trigemino-specific segmental or supra-segmental pathways. In view of the greater effect on CHEP than on nBR, a supra-segmental mechanism seems more likely. 

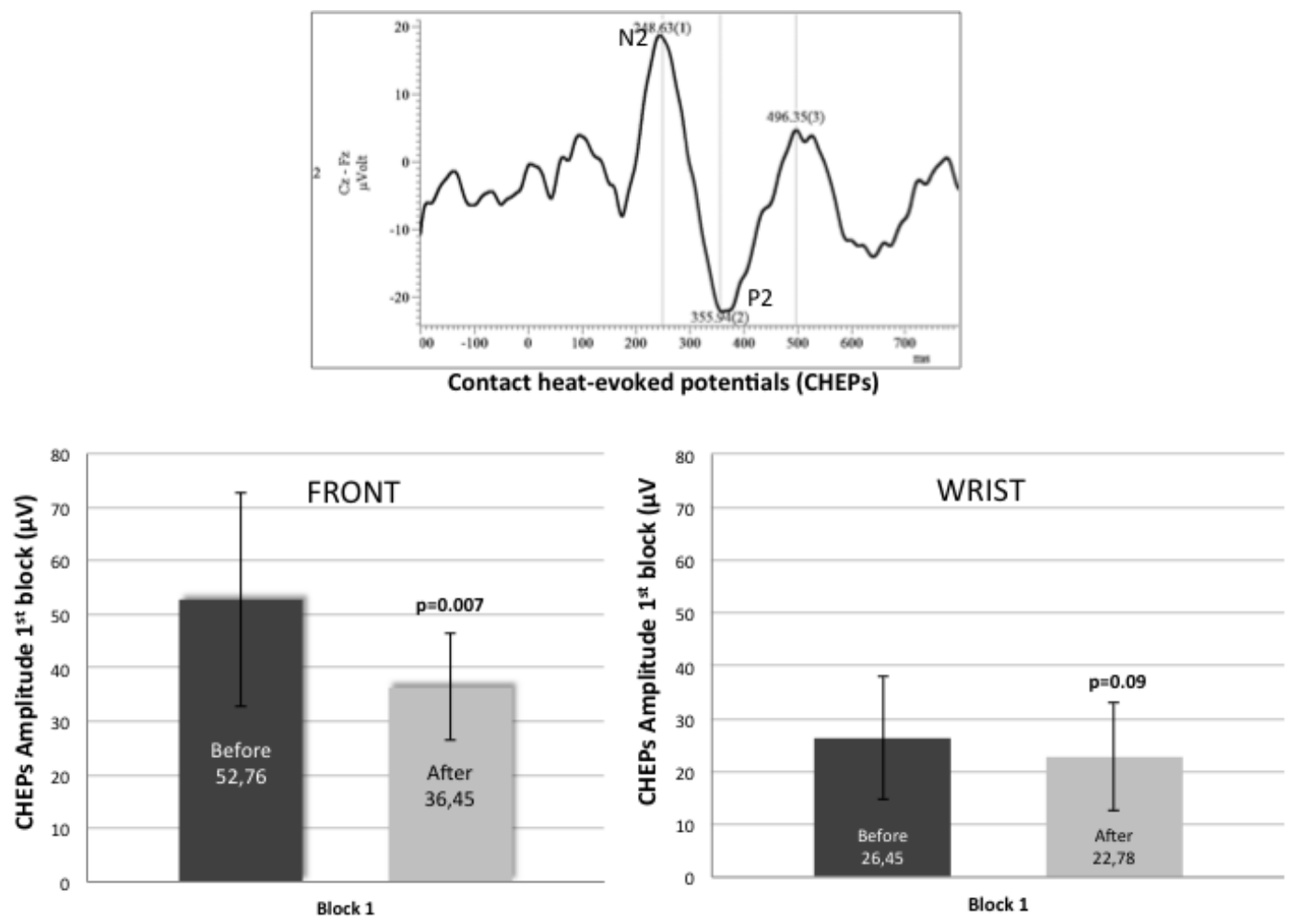

Figure 2: Contact heat-evoked potential (CHEP) recorded over the scalp after heat stimulation at the front or at the wrist in 15 migraine without aura patients. Upper panel: illustrative recording of 5 averaged responses in one patient. Lower panels: amplitude of the $1^{\text {st }}$ block of 5 responses before and immediately after one 20 min session of eTNS (left: heat stimulation of the front; right: heat stimulation at the wrist.

\subsection{Supra-segmental mechanisms}

The $1^{\text {st }}$ indication for a central effect of the Cefaly ${ }^{\circledR}$ came from a double-blinded, cross-over, sham-controlled trial in 30 healthy volunteers that assessed its effects on psychomotor tests (43). This study found that reaction time in a psychomotor vigilance task and score on the Fatigue Visual Numeric Scale were significantly increased after one $20 \mathrm{~min}$ session of eTNS at $120 \mathrm{~Hz}$, while critical flicker fusion frequency was decreased, which suggested that the device had produced a mild, transient sedative effect. Whether such an effect contributes to the therapeutic benefit of Cefaly ${ }^{\circledR}$ is uncertain, the more so that in clinical practice the highest stimulation frequency used is $100 \mathrm{~Hz}$, the protocol recommended for attack treatment.
We have recently published the results of a fluoro-deoxyglucose (FDG)-PET study that analysed brain metabolism in 14 patients suffering from episodic migraine without aura before, immediately after one 20-min session and after a 3-months treatment period of daily 20-min sessions of supraorbital eTNS with the Cefaly ${ }^{\circledR}(60 \mathrm{~Hz}$, 16mA) (44). Baseline FDG-PET revealed a significant hypometabolism of orbitofrontal (OFC), rostral anterior cingulate cortices (rACC) and middle temporal lobe, compared to a control group of healthy volunteers. There was no significant metabolic change after one session of eTNS. By contrast, after 3 months of daily stimulation, frequency of monthly migraine days significantly decreased in 10 compliant patients who performed at least $30 \%$ of the 90 recommended sessions. An in-built software 
that records number of sessions and time of use monitored compliance. In these patients the OFC and rACC hypometabolism was significantly reduced after 3 months (Fig. 3).

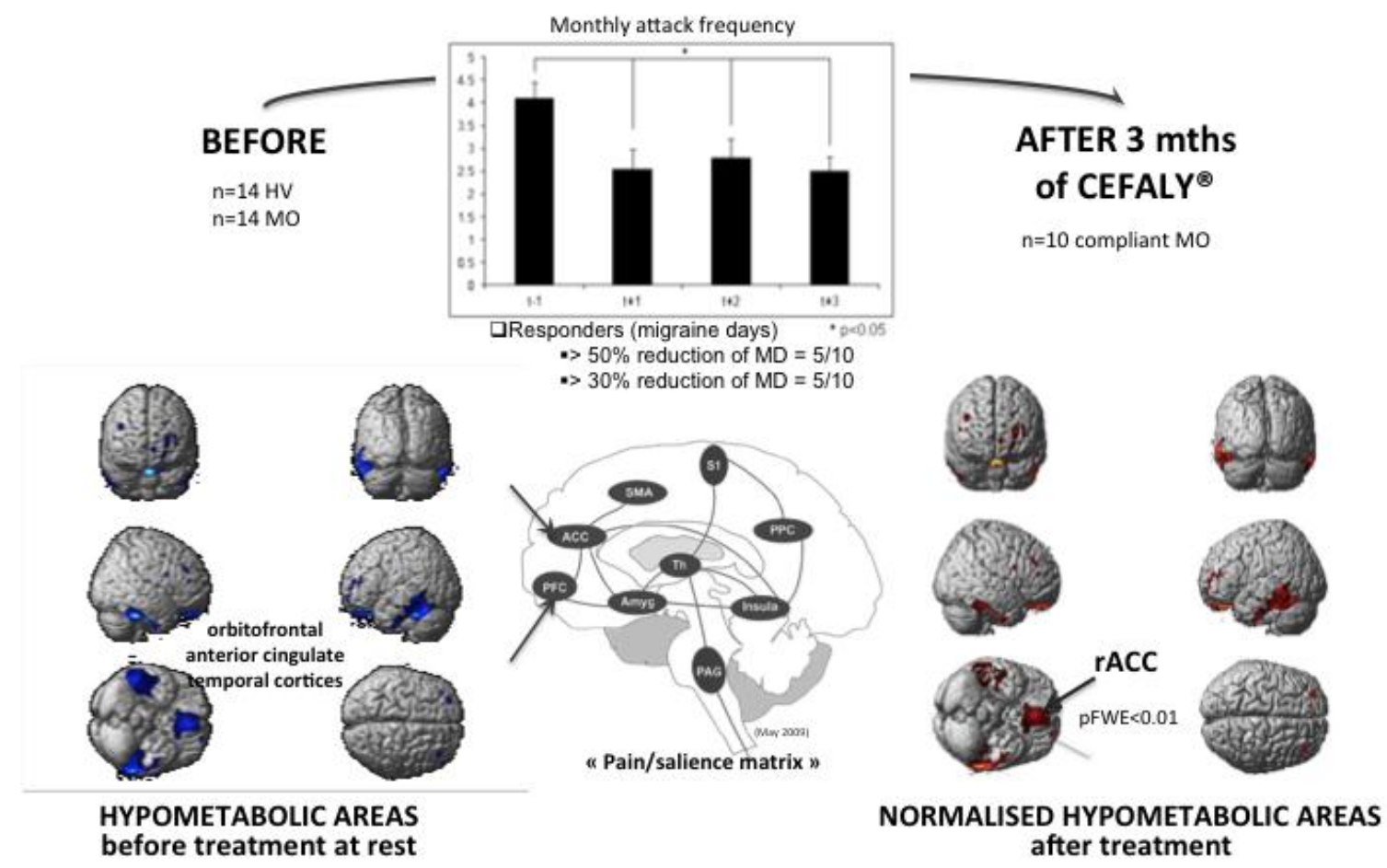

Figure 3: Histogram of changes in monthly migraine attack frequency before and after 1, 2 and 3 months of Cefaly ${ }^{\circledR}$ treatment in 10 out of 14 compliant migraine without aura (MO) patients. Brain areas with a significantly different glucose uptake overlaid over an MRI anatomical map: hypometabolic areas in MO before treatment compared to 14 healthy volunteers (HV) (left panel); areas with increased metabolism after treatment in 10 compliant MO patients (right panel). In the middle: schematic representation of brain areas belonging to the pain/salience matrix after May 2009. rACC: rostral anterior cingulate cortex. pFWE: $\mathrm{p}$ corrected for multiple comparisons (family wise error corrected) (modified after 44).

The change in OFC/rACC metabolism and the progressive reduction of migraine attack frequency with eTNS might suggest that the treatment exerts a slow central neuromodulatory effect, akin other peripheral nerve stimulations (see 45 for a review). Interestingly, Russo et al. (46) have reported in the perigenual part of the ACC greater fMRI BOLD activation after trigeminal noxious heat stimulation in migraine patients than in healthy volunteers. In a follow-up study, the same authors (47) found that this noxious heat-induced BOLD activation was significantly reduced after 2month eTNS with the Cefaly ${ }^{\circledR}$ in $16 \mathrm{MO}$ patients (Fig. 4). 


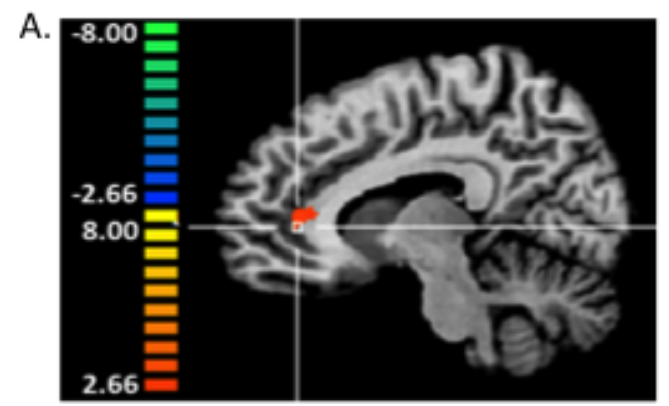

B.

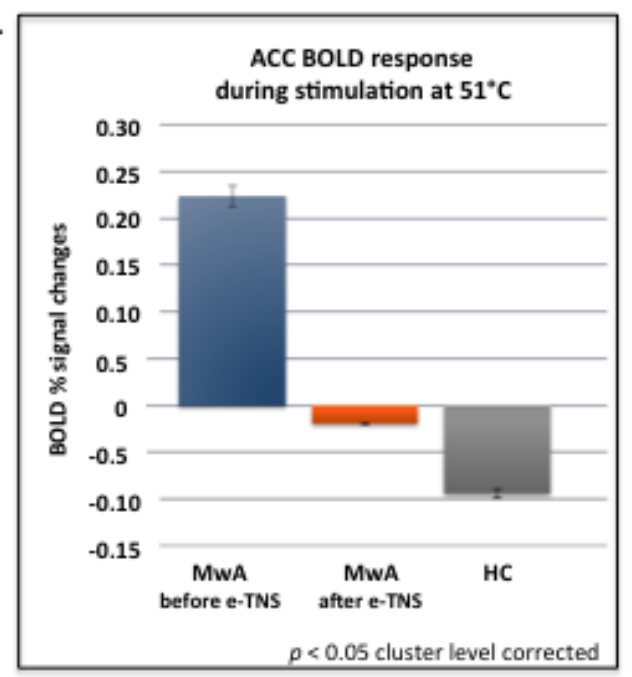

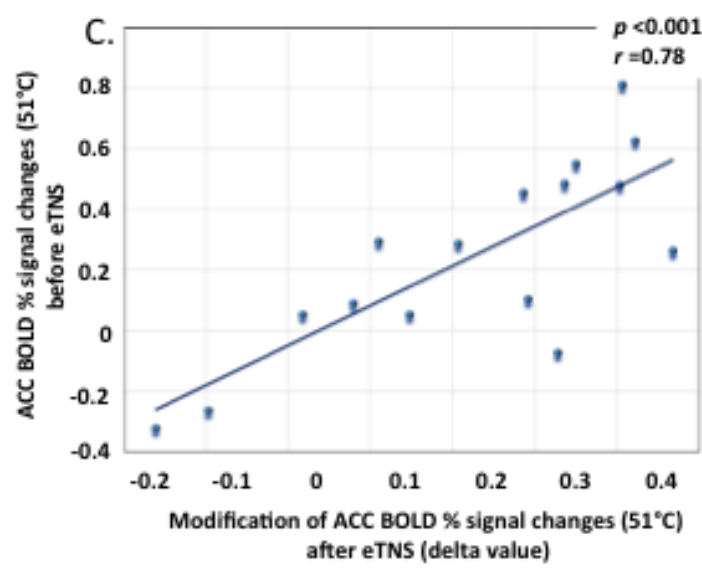

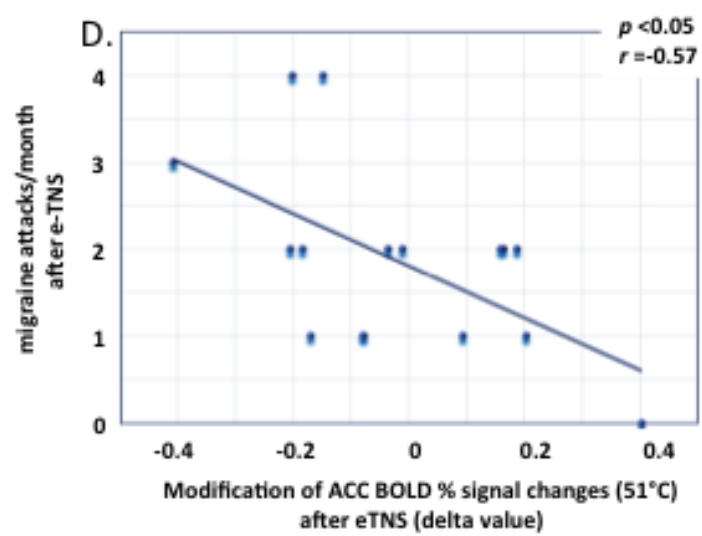

Russo et al. 2016

Figure 4: Significantly different BOLD-response between MwA patients before eTNS treatment and $\mathrm{HC}$ and between MwA patients before and after eTNS treatment. A) T-map of statistically significant differences between groups overlaid onto a Talairach transformed Colin-27 T1 highresolution anatomical template; B) Bar graphs of percent BOLD signal changes at Talairach coordinates $(\mathrm{x}, \mathrm{y}, \mathrm{z})$ : right $\mathrm{ACC}=12,35,7$ during noxious trigeminal heat stimulation at $51^{\circ} \mathrm{C}$ in MwA patients before and after eTNS treatment and the HC group. C) Scatterplot showing significant correlations between ACC BOLD response to noxious heat before eTNS (y-axis) and the modification of the heat-induced ACC BOLD response after eTNS (i.e. the "delta value") (xaxis). D) Scatterplot showing significant correlations between modifications of the heat-induced ACC BOLD response changes after eTNS (x-axis) and post-treatment migraine attack frequency/month (y-axis) MwA: migraine without aura. HC: healthy controls (modified after 47).

Functional neuroimaging studies in chronic cluster headache (48) and chronic migraine patients (49) have shown that percutaneous occipital nerve stimulation is able to increase metabolism in central areas belonging to descending pain control centres, including the ACC, but leave unchanged disease-specific structures like the hypothalamus in cluster headache or the dorsal pons in migraine. By the same token, long electrical stimulations of the trigeminal ganglion in patients with trigeminal neuropathic pain increased regional blood flow in the ACC, OFC and medial frontal cortices, which was correlated with pain relief (50). Finally, opioid and placebo analgesia are also associated with increased 
activity of OFC and rACC, suggesting a common underlying mechanism (51).

A last piece of experimental evidence arguing in favour of a suprasegmental action of eTNS comes from a study by Di Lenola et al. (52). These authors measured in migraine patients between attacks the effect of one 20 min session with Cefaly $^{\circledR}$ of high frequency oscillations (HFO) embedded in somato-sensory evoked cortical potentials, which reflect thalamocortical activity and are decreased, indicating thalamo-cortical, in migraine (53). After eTNS, they found a significant increase in HFO. It remains, however, to be determined if there is a relation between this finding and the eTNS-induced changes in activity of medial frontal cortex areas.

\section{Conclusion}

Taken together, the above described studies suggest that eTNS with the Cefaly ${ }^{\circledR}$ exerts its preventive anti-migraine action chiefly at supra-segmental levels, i.a. by modulating activity of medial frontal cortex areas involved in the control of the affective and cognitive dimensions of pain. These areas play indeed a paramount role in individual levels of central pain modulation in healthy subjects (54) and are dysfunctioning in chronic migraine (49), medication overuse headache (55) and chronic cluster headache (48). They are modulated both by transcutaneous and percutaneous pericranial nerve stimulation. The fact that involvement of medial frontal cortex areas seems not specific to migraine, nor limited to pain, and that eTNS can change thalamo-cortical circuits, may explain why pericranial neurostimulation, including eTNS, was reported to have also therapeutic effects in tension-type headache (56), fibromyalgia (57), depression (58) and epilepsy (59).

Regarding the acute effects of eTNS during a migraine attack, the mechanism of action might be different. The preventive eTNS effect on migraine takes time and becomes maximal after 3 months in the PREMICE trial (24), which is compatible with slow modulation of central pain control centres. By contrast, the acute analgesic effect of Cefaly ${ }^{\circledR}$ (30) and its inhibitory action on the nociceptive blink reflex during attacks (28) peak at $1 \mathrm{~h}$ and tend to decrease thereafter, suggesting a transient inhibition of trigeminal nociception at the segmental level.

The predominant mode and site of Cefaly ${ }^{\circledR,}$ s action could thus differ between its acute effects, possibly exerted segmentally via somatic afferent-induced blockade of nociceptive trigeminovascular afferents, and its preventive effects, probably depending on activation of cortical areas controlling pain and its emotional aspects. Interestingly, the two mechanisms are intermingled in most $\mathrm{Cefaly}^{\circledR}$-treated migraine patients, as they tend to use it both for prevention and for attack treatment.

\section{Conflict of interest}

Jean Schoenen is a consultant for Cefaly Technology.

\section{Acknowledgement}

The author is grateful to A. Russo for preparing figure 4 . 


\section{References}

1. Marmura MJ, Silberstein SD, Schwedt TJ. The acute treatment of migraine in adults: the american headache society evidence assessment of migraine pharmacotherapies. Headache 2015;55:3-20. doi:

10.1111/head.12499

2. Silberstein SD, Latsko M, Schoenen J. Preventive Antimigraine Drugs. In Multidisciplinary Management of Migraine. Chap 10. pp91-102. Eds Fernandez-de-las-Penas C, Chaitow L, Schoenen J. Contemporary issues in Physical therapy and Rehabilitation Medicine. Jones \& Bartlett Learning. Burlington USA. 2012.

3. Evers S, Afra J, Frese A, Goadsby PJ, Linde M, May A, Sándor PS; European Federation of Neurological Societies. EFNS guideline on the drug treatment of migraine--revised report of an EFNS task force. Eur J Neurol. 2009 Sep;16(9):968-81. doi: 10.1111/j.1468-1331.2009.02748.x.

4. Paemeleire, K., Magis, D., Schoenen, J. Migraine, Medical treatment of migraine. In Reference Module in Neuroscience and Biobehavioral Psychology, pp 1-5. Elsevier 2017.

5. Schoenen J \& Magis D. Herbal Medicines and Vitamins. In "Migraines and Other Headache Disorders".Chap 23. pp 363-374. Eds Lipton RB \& Bigal ME.Informa Healthcare. New York 2006

6. Gallagher RM, Kunkel R. Migraine medication attributes important for patient compliance: concerns about side effects may delay treatment. Headache 2003;43:36-43.
7. Berger A, Bloudek LM, Varon SF, Oster G. Adherence with migraine prophylaxis in clinical practice. Pain Pract 2012;12:541-9. doi: 10.1111/j.1533-2500.2012.00530.x

8. Blumenfeld AM, Bloudek LM, Becker WJ, Buse DC, Varon SF, Maglinte GA, et al. Patterns of use and reasons for discontinuation of prophylactic medications for episodic migraine and chronic migraine: Results from the second international burden of migraine study (IBMS-II). Headache. 2013;53(4):644-55.

9. Turner DP, Golding AN, Houle TT. Using a graphical risk tool to examine willingness to take migraine prophylactic medications. Pain. 2016 Oct;157(10):2226-2234.

10. Lipton RB, Buse DC, Serrano D, Holland S, Reed ML. Examination of unmet treatment needs among persons with episodic migraine: results of the American Migraine Prevalence and Prevention (AMPP) Study. Headache. 2013 Sep;53(8):1300-11. doi: 10.1111/head.12154.

11. Ambrosini A, D'Alessio C, Magis D, Schoenen J. Targeting pericranial nerve branches to treat migraine: Current approaches and perspectives. Cephalalgia. 2015 Dec;35(14):130822. doi: $10.1177 / 0333102415573511$. Review.

12. Ghoname EA, Craig WF, White PF. Use of percutaneous electrical nerve stimulation (PENS) for treating ECTinduced headaches. Headache. 1999 Jul-Aug; 39(7):502-5. 
13. Ahmed HE, White PF, Craig WF, Hamza MA, Ghoname ES, Gajraj NM. Use of percutaneous electrical nerve stimulation (PENS) in the short-term management of headache. Headache. 2000 Apr;40(4):311-5.

14. Saper JR, Dodick DW, Silberstein SD, McCarville S, Sun M, Goadsby PJ; ONSTIM Investigators. Occipital nerve stimulation for the treatment of intractable chronic migraine headache: ONSTIM feasibility study. Cephalalgia. 2011 Feb;31(3):271-85. doi: $10.1177 / 0333102410381142$.

15. Silberstein SD, Dodick DW, Saper J, Huh B, Slavin KV, Sharan A, Reed K, Narouze S, Mogilner A, Goldstein J, Trentman T, Vaisman J, Ordia J, Weber P, Deer T, Levy R, Diaz RL, Washburn SN, Mekhail N. Safety and efficacy of peripheral nerve stimulation of the occipital nerves for the management of chronic migraine: results from a randomized, multicenter, doubleblinded, controlled study. Cephalalgia. 2012 Dec;32(16):1165-79. doi: $10.1177 / 0333102412462642$.

16. Dodick DW, Silberstein SD, Reed KL, Deer TR, Slavin KV, Huh B, Sharan AD, Narouze S, Mogilner AY, Trentman TL, Ordia J, Vaisman J, Goldstein J, Mekhail N. Safety and efficacy of peripheral nerve stimulation of the occipital nerves for the management of chronic migraine: long-term results from a randomized, multicenter, doubleblinded, controlled study. Cephalalgia. 2015 Apr;35(4):344-58. doi: $10.1177 / 0333102414543331$.

17. Reed KL, Black SB, Banta CJ, Will KR. Combined occipital and supraorbital neurostimulation for the treatment of chronic migraine headaches: initial experience. Cephalalgia 2010;30:26071. doi: 10.1111/j.14682982.2009.01996.x

18. Schwedt TJ. Neurostimulation for primary headache disorders. Curr Neurol Neurosci Rep. 2009;9:101-7.

19. Schoenen J, Roberta B, Magis D, Coppola G. Noninvasive neurostimulation methods for migraine therapy: The available evidence. Cephalalgia. 2016 Mar 29; . Epub 2016 Mar 29.

20. Solomon S, Guglielmo KM. Treatment of headache by transcutaneous electrical stimulation. Headache 1985 Jan;25(1):12-5.

21. Lapeer GL. High-intensity transcutaneous nerve stimulation at the Hoku acupuncture point for relief of muscular headache pain. Literature review and clinical trial. Cranio. 1986 Apr;4(2):164-71.

22. Heydenreich transcutaneous A. [Localized stimulation with high voltage impulses in functional chronic headache and migraine]. $\mathrm{Z}$ Arztl Fortbild (Jena). 1991 Jan 25;85(12):37-9.

23. Taubert K. [Transcutaneous electric nerve stimulation (TENS) in headache and facial pain]. Z Arztl Fortbild (Jena). 1991 Jan 25;85(1-2):31-6.

24. Schoenen J, Vandersmissen B, Jeangette S, Herroelen L, Vandenheede M, Gérard P, Magis D. Migraine prevention with a supraorbital 
transcutaneous stimulator: a randomized controlled trial. Neurology. 2013;80(8):697-704. doi: 10.1212/WNL.0b013e3182825055.

25. Bussone G, Diener HC, Pfeil J, Schwalen S. Topiramate $100 \mathrm{mg} /$ day in migraine prevention: a pooled analysis of double-blind randomised controlled trials. Int J Clin Pract 2005;59:961-968.

26. Russo A, Tessitore A, Conte F, Marcuccio L, Giordano A, Tedeschi G. Transcutaneous supraorbital neurostimulation in "de novo" patients with migraine without aura: the first Italian experience. J Headache Pain. 2015;16:69. doi: 10.1186/s10194-015-0551-3.

27. Magis D, Sava S, d'Elia TS, Baschi R, Schoenen J. Safety and patients' satisfaction of transcutaneous supraorbital neurostimulation (tSNS) with the Cefaly ${ }^{\circledR}$ device in headache treatment: a survey of 2,313 headache sufferers in the general population. J Headache Pain. 2013;14:95. doi: 10.1186/1129-2377-14-95.

28. Gérardy PY, Fabry D, Fumal A, Schoenen J. A pilot study on supraorbital surface electrotherapy in migraine. Cephalalgia. 2009;29(1):134. doi: 10.1111/j.14682982.2008.01798_1.x (Poster Abstract).

29. Kozminski M. () Transcutaneous supraorbital nerve stimulation as a rescue therapy. Headache. 2014;54(S1):12. doi:10.1111/head.12405 (Poster Abstract).
30. Chou DE, Gross GJ, Casadei CH, Yugrakh MS. External trigeminal nerve stimulation for the acute treatment of migraine: open trial on safety and efficacy. Headache 2016 Jun 9; 56 (suppl 1):55 (Poster Abstract).

31. Penning, S. \& Schoenen, J. A survey on migraine attack treatment with the CEFALY® device in regular users. Acta Neurol Belg. 2017. doi:10.1007/s13760-017-0757-z

32. Ersek RA. Transcutaneous electrical neurostimulation: a new therapeutic modality for controlling pain. Clin Orthop Relat Res. 1977 Oct;(128):31424.

33. Melzack R, Wall PD. Pain mechanisms: a new theory. Science. 1965 Nov 19;150(3699):971-9. Review.

34. Melzack R, Wall PD. Acupuncture and transcutaneous electrical nerve stimulation. Postgrad Med J. 1984 Dec;60(710):893-6.

35. Jones I, Johnson MI. Transcutaneous electrical nerve stimulation. Continuing Education in Anaesthesia, Critical Care \& Pain 2009;9 (4): 130135

36. Schueler M, Neuhuber WL, De Col R, Messlinger $\mathrm{K}$. Innervation of rat and human dura mater and pericranial tissues in the parieto-temporal region by meningeal afferents. Headache. 2014 Jun;54(6):996-1009. doi: 10.1111/head.12371.

37. Didier HA, Di Fiore $P$, Marchetti C, Tullo V, Frediani F, Arlotti M, Giannì $\mathrm{AB}$, Bussone G. Electromyography 
data in chronic migraine patients by using neurostimulation with the Cefaly® device. Neurol Sci. 2015 May;36 Suppl 1:115-9. doi: 10.1007/s10072-015-2154-9.

38. Coppola G, Schoenen J. Cortical excitability in chronic migraine. Curr Pain Headache Rep. 2012;16:93-100. doi: $10.1007 / \mathrm{s} 11916-011-0231-1$

39. Bartsch T, Goadsby PJ. Stimulation of the occipital nerve induces increased central excitability of dural afferent input. Brain 2002;125(Pt 7):1496-509

40. Jürgens TP, Busch V, Opatz O, SchulteMattler WJ, May A. Low-frequency short-time nociceptive stimulation of the greater occipital nerve does not modulate the trigeminal system. Cephalalgia. 2008 Aug;28(8):842-6. doi: 10.1111/j.1468-

2982.2008.01612.x.

41. Aymanns M, Yekta SS, Ellrich J. Homotopic long-term depression of trigeminal pain and blink reflex within one side of the human face. Clin Neurophysiol. 2009 Dec;120(12):2093-9. doi: 10.1016/j.clinph.2009.08.027.

42. Cruccu G, Truini A. Neurostimulation therapy (acupuncture-like) and longterm depression: a challenge for the clinical neurophysiologist. Clin Neurophysiol. 2009 Dec;120(12):2004-5. doi: 10.1016/j.clinph.2009.09.017.

\section{Piquet M, Balestra C, Sava SL,} Schoenen J. Supraorbital transcutaneous neurostimulation has sedative effects in healthy subjects.
BMC Neurol 2011;11:135. doi: 10.1186/1471-2377-11-135

44. Magis D, D'Ostilio K, Thibaut A, De Pasqua V, Gerard P, Hustinx R, Laureys $\mathrm{S}$, Schoenen J. Cerebral metabolism before and after external trigeminal nerve stimulation in episodic migraine. Cephalalgia. 2016 Jun 23. pii: 0333102416656118.

45. Schwedt TJ, Chiang C, Chong CD, Dodick DW. Functional MRI of migraine. Lancet Neurol. Elsevier Ltd; 2015;14(1):81-91.

46. Russo A, Tessitore A, Esposito F, Marcuccio L, Giordano A, Conforti R, Truini A, Paccone A, d'Onofrio F, Tedeschi G. Pain processing in patients with migraine: an eventrelated fMRI study during trigeminal nociceptive stimulation. J Neurol. 2012 Sep;259(9):1903-12. doi: 10.1007/s00415-012-6438-1.

47. Russo A, Tessitore A, Esposito F, Di Nardo F, Silvestro M, Trojsi F, De Micco R, Marcuccio L, Schoenen J, Tedeschi G. Functional changes of the pain processing network after external trigeminal neurostimulation in migraine patients Neurol Sci. 2016, 37 Suppl, S15-16

48. Magis D, Bruno MA, Fumal A, et al. Central modulation in cluster headache patients treated with occipital nerve stimulation: an FDGPET study. BMC Neurol 2011;11(1):25. doi: 10.1186/14712377-11-25.

49. Matharu MS, Bartsch T, Ward N, Frackowiak RS, Weiner R, Goadsby PJ. Central neuromodulation in chronic 
migraine patients with suboccipital stimulators: a PET study. Brain. 2004 Jan;127(Pt 1):220-30.

50. Willoch F, Gamringer U, Medele R, Steude U, Tölle TR. Analgesia by electrostimulation of the trigeminal ganglion in patients with trigeminopathic pain: a PET activation study. Pain. 2003 May;103(1-2):11930.

51. Petrovic P, Kalso E, Petersson KM, Ingvar $M$. Placebo and opioid analgesia-- imaging a shared neuronal network. Science. 2002;295(2002):1737-40.

52. Di Lenola D, Coppola G, Serrao M, Di Lorenzo C, Pierelli F. Transcutaneous supraorbital nerve stimulation enhances somatosensory thalamic activity in migraine between attacks: a central mechanism of clinical efficacy? J Headache Pain. 2015 Dec;16(Suppl 1):A160. doi: 10.1186/1129-2377-16S1-A160.

53. Coppola G., Vandenheede M., Di Clemente L., Ambrosini A., Fumal A., De Pasqua V., Schoenen J. Somatosensory evoked highfrequency oscillations reflecting thalamo-cortical activity are decreased in migraine patients between attacks. Brain 2005, 128: 98103

54. Bogdanov VB, Viganò A, Noirhomme Q, Bogdanova OV, Guy N, Laureys S, Renshaw PF, Dallel R, Phillips C, Schoenen J. Cerebral responses and role of the prefrontal cortex in conditioned pain modulation: an fMRI study in healthy subjects. Behav Brain
Res. 2015 Mar 15;281:187-98. doi: 10.1016/j.bbr.2014.11.028.

55. Fumal A, Laureys S, Di Clemente L, Boly $M$, Bohotin $V$, Vandenheede $M$, Coppola G, Salmon E, Kupers R, Schoenen J. Orbitofrontal cortex involvement in chronic analgesicoveruse headache evolving from episodic migraine. Brain. 2006 Feb;129(Pt 2):543-50.

56. Farahani DM, Tavallaie SA, Ahmadi K, Ashtiani AF. Comparison of Neurofeedback and Transcutaneous Electrical Nerve Stimulation Efficacy on Treatment of Primary Headaches: A Randomized Controlled Clinical Trial. Iranian Red Crescent Medical Journal. 2014 Aug;16(8).

57. Plazier M, Dekelver I, Vanneste $S$, Stassijns G, Menovsky T, Thimineur M, De Ridder D. Occipital nerve stimulation in fibromyalgia: a doubleblind placebo-controlled pilot study with a six-month follow-up. Neuromodulation. 2014 Apr;17(3):256-63; discussion 263-4. doi: $10.1111 /$ ner.12121.

58. Cook IA, Abrams M, Leuchter AF. Trigeminal Nerve Stimulation for Comorbid Posttraumatic Stress Disorder and Major Depressive Disorder. Neuromodulation. 2016 Apr;19(3):299-305. doi: 10.1111/ner.12399.

59. DeGiorgio CM, Soss J, Cook IA, Markovic D, Gornbein J, Murray D, Oviedo S, Gordon S, Corralle-Leyva G, Kealey CP, Heck CN. Randomized controlled trial of trigeminal nerve stimulation for drug-resistant epilepsy. Neurology. 2013 Feb 
26;80(9):786-91.

doi:

10.1212/WNL.0b013e318285c11a. 